\title{
Erratum
}

\section{Partnerships in International Policy-Making}

Civil Society and Public Institutions in European and Global Affairs

Raffaele Marchetti

(C) The Editor(s) (if applicable) and The Author(s) 2017

R. Marchetti (ed.), Partnerships in International Policy-Making, International Series on Public Policy, DOI 10.1057/978-1-349-94938-0

DOI 10.1057/978-1-349-94938-0_16

The original book was published without the references in the print and online versions of the below chapters. The references are listed below:

The updated online version of the book can be found at http://dx.doi.org/10.1057/978-1-349-94938-0 


\section{References}

\section{Chapter 5}

Bezember, Dirk, and Derek Heady. 2008. Agriculture, development and urban bias. World Development, 38(8): 1342-1364

Boettke, P. et al. (2008). "Institutional stickiness and the new development economics," The American Journal of Economics and Sociology, 67(2): 331-358.

Boggs, C., \& Thale, G. (2013). Government investment in family agriculture: New opportunities in Mexico and Central America, p. 2. Washington, DC: Washington Office on Latin America. Retrieved from http://www.wola.org/ files/Government_Investment_in_Family\%20Agriculture.pdf

Booth, D. (2014). Agricultural policy choice: Interests, ideas and the scope for reform. IIED Working Paper September 2014. London: International Institute for Environment and Development (IIED).

Booth, D. (Ed.). (2015). Developmental Regimes in Africa: Initiating and sustaining developmental regimes in Africa - Synthesis Report. London: Overseas Development Institute. Retrieved from http://www.institutions-africa.org/ filestream/20150216-developmental-regimes-in-africa-synthesis-report

Dreher, A. (2006). "IMF and economic growth: The effects of programs, loans and compliance with conditionality," World Development, 35(5): 769-788.

Driscoll, R. and Evans, A. (2005). Second-generation poverty reduction strategies: New opportunities and emerging issues. Development Policy Review, 23(1): 5-25.

Fernandez, I., Berdegué, J., \& Rosada, T. (2011). Diálogo de políticas para el desarrollo rural: Informe Regional, Apoyando la puesta en marcha de la Estrategia del FIDA. Retrieved form http://rimisp.org/wp-content/files_mf/ 1430878216InformeregionaldialogodepoliticasRIMISP.pdf

IFAD. (2014). IFAD's emerging approach to country-level policy engagement. Retrieved from http://www.ifad.org/pub/policy/policy-engagement.pdf

IFAD. (2015). Policy case studies: Supporting public hearings on the East African Community cooperative societies bill. Retrieved from http://www.ifad.org/ clpe/case/case_eac.pdf

IFAD. (2015). Policy case studies: Exchange on good practices for public consultation. Retrieved from http://www.ifad.org/clpe/case/case_tajikistan.pdf

IFAD. (2016). Country-level policy engagement in IFAD: A review of experience. Retrieved from http://www.ifad.org/pub/policy/clpe.pdf

Jenkins, R. (1991). "The political economy of industrialization: A comparison of Latin American and East Asian newly industrializing countries," Development and Change 22 (1991): 197-231.

Kydd, J. et al. (2004). "Agricultural development and pro-poor economic growth in sub-Saharan Africa: Potential and policy," Oxford Development Studies, 32(1): 37-57. 
Lipton, M. (1977). Why poor people stay poor: Urban bias in world development. Cambridge, MA: Harvard University Press.

Olson, M. (1965). The logic of collective action: Public goods and the theory of groups. Cambridge, MA: Harvard University Press.

Stasavage, David. 2005. Democracy and education spending in Africa. American Journal of Political Science, 49(2): 343-358.

World Bank (2008). World Development Report 2008: Agriculture for development. Washington, DC: World Bank.

The updated original online version for this chapter can be found at http://dx.doi.org/10.1057/978-1-349-94938-0_5

\section{Chapter 6}

Carothers, T., \& Brechenmacher, S. (2014). Closing space: Democracy and Human Rights support under fire. Carnegie Endowment for International Peace, 61. Retrieved from http://carnegieendowment.org/files/closing_space.pdf

Chin, J. (2015). China cracks down on Foreign Nonprofits Beijing treats civic groups as security risks, considers stricter oversight. Wall Street Journal, Retrieved March 6, 2015, from http://www.wsj.com/articles/china-cracksdown-on-foreign-nonprofits-1425694223

Li, Y. (Ed.). (2011). NGOs in China and Europe: Comparisons and contrasts. Burlington, VT: Ashgate.

Mayer, L. H. (2011). NGO standing and influence in regional human rights courts and commissions. Brooklyn Journal of International Law 1(1): 911-946.

Naim, M. (2009). What is a GONGO?: How government-sponsored groups masquerade as civil society. Foreign Policy, Retrieved October 13, 2009, from, http://foreignpolicy.com/2009/10/13/what-is-a-gongo/

Pace, W. R., \& Thieroff, M. (1999). Participation of non-governmental organizations. In R. S. Lee (Ed.), The International criminal court: The making of the Rome Statute, issues, negotiations, results (pp. 391-398). The Hague: Kluwer Law International.

Sunga, L. S. (2007). Dilemmas facing NGOs in coalition-occupied Iraq. In D. A. Bell \& J.-M. Coicaud (Eds.), Ethics in action: The ethical challenges of international buman rights nongovernmental organizations (pp. 99-116). Cambridge University Press.

Sunga, L. S. (2009). What effect if any will the UN human rights council have on special procedures? In J. Grimheden, G. Alfredsson, B. G. Ramcharan, \& A. de Zayas (Eds.), International human rights monitoring mechanisms (2nd ed., pp. 169-183). 
Sunga, L. S. (2011). What should be the UN human rights councils role in investigating genocide, war crimes and crimes against humanity? In M. C. Bassiouni \& W. A. Schabas (Eds.), New challenges for the UN human rights machinery: What future for the UN treaty body system and the human rights council procedures? (pp. 319-349).

Sunga, L. S. (2015). Has the ICC unfairly targeted Africa or has Africa unfairly targeted the ICC?. In T. Mariniello (Ed.), The international criminal court in search of its purpose and identity (pp. 147-173). Routledge.

The updated original online version for this chapter can be found at http://dx.doi.org/10.1057/978-1-349-94938-0_6

\section{Chapter 15}

Barnett, M., \& Weiss, T. G. (2011). Humanitarianism contested: Where angels fear to tread (p. 91). New York: Routledge.

Browne, S. (2006). Aid and influence (pp. 9-10). London: Eahscan.

Crawford, G. (2001). Foreign aid and political reform (p. 65 ). New York: Palgrave.

Goldgeier, J. M., \& McFaul, M. (2003). Power and purpose: U.S. policy toward Russia after the Cold War. Washington DC: Brookings.

Grilli, E. R. (1993). The European Community and the developing countries (p. 7). Cambridge: Cambridge University Press.

Groves, L. \& Hinton, R. 2013. The complexity of aid. In L. Groves \& R. Hinton (Eds.), Inclusive aid: Changing power and relationships in international development (p. 11). London: Routledge.

Jo Crottya, S. M. H., \& Ljubownikowc, S. (2014). Post-Soviet civil society development in the Russian Federation: The impact of the NGO Law. Europe-Asia Studies, 66(8), 1253-1269.

Krasner, S. (1999). Sovereignty organized bypocrisy. Princeton, NJ: Princeton University Press.

Lancaster, C. (2008). Foreign aid: Diplomacy, development, domestic politics (pp. 28-29). Chicago: University of Chicago Press.

Mawdsley, E. (2012). From recipient to donor: Emerging powers and the changing development landscape (p. 35). New York: Zed Books.

Pellicciari, I. (2014). Война за право помощии (War for Aid)-Международная жизнь (International Affairs), III, 64-67.

Pellicciari, I. (2015). Aiuti come Armi. La Russia in cerca di soft power (Aid as a weapon. Russia in seek of soft power), LIMES, II, 159-166.

Pupavac, V. (2006). The politics of emergency and the demise of the developing state: problems for humanitarian advocacy. Development in Practice 16(3/4), 258. 
Robb, C. (2013). Changing power relations. In L. Groves \& R. Hinton (Eds.), Inclusive aid: Changing power and relationships in international development (p. 30). London: Routledge.

Schweller, R. (1999). Realism and the present great powers system: Growth and positional confilct over scarce resources. In E. B. Kapstein \& M. Mastanduno (Eds.), Unipolar politics: Realism and state strategies after the Cold War (pp. 28-68). New York: Columbia University Press.

Sundstrom, L. M. (2006 ). Funding civil society: Foreign assistance and NGO development in Russia (Stanford, CA: Stanford University Press).

Weber, S. (1995). European Union conditionality. In B. Eichengreen et al. (Eds.), Politics and institutions in an integrated Europe (pp. 193-220). Berlin: Springer-Verlag.

The updated original online version for this chapter can be found at http://dx.doi.org/10.1057/978-1-349-94938-0_15 